\title{
"Comparative Clinical Study of Dhatri Lauha and Navayasa Lauha in Garbhini Panduroga With Reference To Anemia in Pregnancy"
}

\author{
* Dr.Bhagyashri Mahavir Khot. Dr.Arun Jagannath Patil ${ }^{1}$. \\ Dr.Anil Chindhu kakad ${ }^{2}$. \\ *(Asso.Professor-Streerog-Prasutitantra Dept.R.A.Podar Medical CollegeWorli Mumbai.) . \\ (Asso. Professor-Streerog-Prasutitantra Dept.R.A.Podar Medical College Worli Mumbai) ${ }^{1}$ \\ (P.G.Scholar Streerog-Prasutitantra Dept.R.A.Podar Medical College Worli Mumbai.) ${ }^{2}$
}

\begin{abstract}
Dharti lauha and Navayasa lauha are the two famous ayurvedic preparation that are described in ayurvedic classics for the management in garbhini panduroga (Anemia in pregnancy). A simple random sampling method was followed for the clinical study. The 60 iron deficiency anemia pregnant women age group between 18 to 35 years divided into two group-Group A $(n=30)$ and Group B $(n=30)$ were treated with Dharti lauha and Navayasa lauha respectively. Both drugs provided significant effect on the signs and symptoms of shrama(fatigue), daurbalya(weakness), panduvarna(pallor),hrudrava (palpitation), shwasa (exertional dyspnoea), Bhrama (giddines), anna aruchi (anorexia), Shotha (edema), gatrashool(bodyache).

Dhatri Lauha provided significiant result on $\mathrm{Hb} g m \%, R B C, M C V, P C V$ serum iron percent transferrin saturation and TIBC where as insignificant changes were found in $M C H$ and $M C H C$.

Navayasa Lauha provided significant result on $\mathrm{Hb}$ gm\%.RBC,PCV,MCV,MCH,serum iron,percent transterrin saturation and TIBC where a insignificant results found in $M C H C$.

Dhatri Lauha showed significant result in anemia in pregnancy(Garbhini Pandu)

Keywords:- Dhatri Lauha, Navayasa lauha,Anemia, Panduroga, Iron deficiency anemia.
\end{abstract}

\section{Introduction:}

Anemia is one of the universal problem and there are different types of anemia was explained.Iron deficiency anemia has a very high global incidence affecting approximately $20 \%$ of the world's population. Nearly $50 \%$ of the individual with iron deficiency progress to iron deficiency anemia iron deficiency is not only seen in developing countries with wide spread social and economical depravation but also in developed countries.

In India also depending on age and sex prevalence of iron deficiency anemia (IDA)has been reported to range from $38-72 \%$.Majority of them being woman and children. In Ayurveda anemia is co-related with panduroga.

Panduroga is defined as pitta dominant tridoshaja disease, where vivarnata of twaka (discolouration of skin) is mainly pandu(pallor) due to alpa rakta. Many features are found in anemia,as per modern literature and ayurvedic literature,some subjective parameters which are common in both panduroga and iron deficiency anemia.

Innumerable iron containing allopathic formulations are available in the market for treatment of iron deficiency anemia.The long term treatnent with iron salts is associated with several side effects like heartburn, nausea, upper gastric discomfort, constipation and diarrhoea. Recently it has been shown to generate damaging free radicles in the intestine.

In ayurveda different combination of herbometallic drugs are explained by which these drugs, this disease can be treated successfully and also simultaneously appetite,immunity will get improved without any adverse effects of the drugs in the patient.

Garbhini pandu is a challenging problem to the health of mothers in reproductive life.pregnancy is a state in which all the physiological functions are hyperstimulated in order to meet the demands of the growing fetus, hence woman should take nourishing diet.The rasa and the rakta of the mother are carried to the fetus for its proper growth and development.So this increased demand of nutrition has to be compensated. If not, it leads to dhatukshaya in gorbhini stree. Among the various dietic factors, iron is one which is in great demand by the fetus and placenta most of the women are already suffering from low grade iron deficiency anemia,because of their multi-parity, prolonged lactation, dietic deficiency and worm infestation. When these women conceive the severity of anemia increases.

Due to anemia many complications develop during pregnancy,lobour and in puerperal period these are prematurity,low birth weight babies,congestive cardiac failure, post-partum haemorrhage and infection. 
Aims \& Objectives :

1) To evaluate the effect of Dhatri lauha in Garbhini pandu.

2) To evaluate the effect of Navayasa Lauha in Garbhini Pandu.

3) To evaluate the comparative effect of Dhatri Lauha and Navayasa Lauha in Garbhini Pandu.

\section{Materials \& Methods :}

In present study,"Comparative clinical Study of Dhatri Lauha and Navayasa Lauha in garbhini panduroga with reference to anemia in pregnancy" was carried out on 30 patients attending the OPD \& IPD of prasuti tantra and stri. rog department, R.A. Podar Government Medical (Ayu) College, Worli, Mumbai - 400 018.

Diagnosis was done on the basis of signs and symptoms of panduroga iron deficiency anemia.Investigations of blood, urine and stool have been carried out to diagnosis and to rule out any other pathology. A simple random sampling method was followed for the clinical study.

\section{Inclusion Criteria :}

- Patients with pratyatma lakshans of pandu.

- Age 18 to 35 yrs.

- Anemia from $4^{\text {th }}$ month of pregnancy onwards will be considered.

\section{Biochemical Parameters :}

- $\mathrm{Hb} 8$ to $10 \mathrm{gm} / \mathrm{dl}$.

- Serum iron (PI) $<37 \mathrm{ug} / \mathrm{dl}$

- Mean corpuscular volume (MCV) below $76 \mathrm{fl}$.

- Total iron binding capacity (TIBC) $>385 \mathrm{ug} / \mathrm{dl}$

- Transferrin saturation $<10 \%$

- $\quad \mathrm{PCV}($ Packed cell volume $)<36 \%$

- $\mathrm{MCHC}<349 / \mathrm{dl}$

\section{Exclusion Criteria :}

- Hemoglobin percentage below 8gm\%

- Pregnancy induced complications like hyperemesis gravidarum, antepartum haemorrhage, preeclamptic toxaemia, eclampsia, diabetes mellites, jaundice.

- Anemia due to other pathology like cardiac, renal, liver disorders, diabetes mellitus,hypertension, thalassaemia,sickle cell anemia, rhumatoid arthritis,worm infestation, acute and chronic blood loss, bleeding disorders hemoglobinopathies and malignancy, and defective absorption like patients of gastrectomy, gastrojejunostomy, sprue syndrome etc.

\section{Investigations-}

1) Haematology - $\mathrm{Hb}$ gm\%, $\mathrm{RBC}$ count, $\mathrm{MCV}, \mathrm{PCV}, \mathrm{MCH}, \mathrm{MCHC}$

2) Blood Bioctemistry - Serum iron, Total iron binding capacity, Transterrin saturation.

3) Other routine ANC check-up investigation

\section{Treatment Schedule :}

Group A - Dhatri Lauha (250)mg T.I.D. in the form of vati, after food for 90 days with ghee / honey. Group B - Navayasa Lauha (250) $\mathrm{mg}$ - T.I.D. in the form of vati food for 90 days with honey/water. In ayurveda the vehicle is very important for success of the therapy.

follow-up period : After completion of therapy.

Pathya-Apathya : (Dietic \& behavioural Regimens)

Pathya-(healthy diet)-

Green leafy vegetables, puran sali (One type of old rice), beet root, bajra, mudga (Phaseolus radiatus) mashur (Lens culinaris), spinach, apple, Amalaki, Kharjur, amranthus spinosus, peanuts, jaggary, mamsa (meat of domestic animals) etc. 
Apathya : (Harmful diet) -

Amla (sour), lavan (salt), kshar (alkali), atiusha (excessive hot), atitikshan (excessive pungent), fermented viruddha \& asatmya ahara (in-compatible and unwholesome food), Divaswapna (day sleep), Ratrijagarana (night awakening) physically \& mentally faligue work, vegadharana (suppression of natural urges).

Criteria for Assessment :

a) The result was assessed on relief of the signs and symptoms of the disease.

b) Biochemical and haematological parameters after completion of the treatement.

\section{Grading the assessement criteria on clinical features :}

A) Daurbalya (Balahani - weakness)

1) No feeling of weakness during daily activities -0

2) Sometimes feeling weakness, but performs daily activities -1

3) Often feeling weakness but affecting daily activities -2

4) Daily activities reduced due to weakness -3

B) Shrama (fatigue) :

1) No shrama except hard work -0

2) Shrama after moderate work for a certain time - 1

3) Shrama after light work for a certain time - 2

4) Shrama after routine activities for a certain time -3

Hard work - weight, lifting, moderate work - playing, running, dancing, light work - Household daily activities. Routine activities - personal hygiene.

C) Panduvarna of Twaka (skin), Netra (sclera), Nakha (nail).

1) Panduta absent in these region -1

2) Panduta absent in one region -2

3) Panduta absent in two region -3

4) Panduta absent in three region -4

D) Hrudrava (Palpitation) :

1) No palpitation -0

2) Mild palpitation with daily activities - 1

3) Palpitation with daily activities -2

4) Palpitation during rest -3

E) Shwasa : (Exertional Dyspnoea) -

1) No exertional dyspnoea - 0

2) Mild dyspnoea with normal activities -1

3) Dyspnoea stops her daily activities intermittently -2

4) Dyspnoea stops her daily activities frequently -3

F) Bhrama (Giddiness)

1) No bhrama - 0

2) Occassionally present (1 to 2 times per week) -1

3) Frequently present (1 to 2 times in a day) -2

4) Persistent (throughout the day) -3

G) Anna Aruchi : (Annadwesha)

1) Normal urge to have a food -0

2) Dislike to have a food - 1

3) dislike to have a food even though hungry and takes food - 2

4) Person dislikes and takes a little bit food - 3

H) Shothas (oedema)

1) No shotha - 1

2) Shotha observed only on legs - 1

3) shotha observed on legs \& face - 2 
4) shotha observed all over body -3

I) Gatrashoola : (Bodyache)

1) No Gatrushoola -0

2) Sometimes Gatrashoola - 1

3) Gatrashoola daily after daily work -2

4) Gatrashoola present even if resting - 3

\section{Assessment of Results :}

The paired ' $t$ ' test \& unpaired ' $t$ ' test were carried out for signs \& symptoms, investigations \& comparison between two groups. Overall effect on signs \& symptoms were calculated by percentage of relief.

\section{Observation \& Results :}

Maximum number of patients in this study reported in 26 to 35 year i.e. $60 \%$ followed by $40 \%$ for patients between 18 to 25 years.

Incidence of pandu roga was seen to be maximum in Hindus $(75 \%)$ followed by muslim $(25 \%)$, patients with mixed diet formed $(80 \%)$ \& vegetarian $(20 \%) .60 \%$ of patients were multigravida and $40 \%$ were primi.

Group A : Provided highly significant effect in relieving shrama (47.91\%), Daurbalya (63.49\%), panduvarna $(15.06 \%)$, hrudrava (51.92\%), shwasa (53.96\%), Bhrama (66.29\%), Anna aruchi $(96.27 \%)$, shotha $(56.21 \%)$, Gatrashoola (87\%).

Group B : Showed highly significant effect in relieving shrama (60.29\%), Daurbalya (83.25\%), Pandu varna (31.29\%), hrudrava (74\%), Shwasa (69.11\%), Bhrama (75.06\%), Annaaruchi $(84 \%)$, shotha $(92.06 \%)$, Gatrashoola (72\%).

\section{Effect of Haemoglobin :-}

Group A - The mean score of $\mathrm{Hb} \%$ which was 9.075 before treatment increased to 10.325 after medication when these values were analysed statistically the scores were highly significant with $\mathrm{P}<0.001$,

Group B - The mean score of $\mathrm{Hb} \%$ which was 8.295 before treatment increased to 9.975 after treatment and was maintained. when those values were analysed statistifally the scores were highly significant with $p<0.001$.

\section{Comparison within groups :}

\begin{tabular}{|c|c|c|c|c|c|c|c|c|}
\hline \multirow[t]{2}{*}{ Group } & \multirow[t]{2}{*}{ No. } & \multirow[t]{2}{*}{ BT } & \multirow[t]{2}{*}{ AT } & \multicolumn{5}{|c|}{ Pajred ' $t$ ' test } \\
\hline & & & & Diff. & $\%$ & S.D. & $\mathbf{t}$ & $\mathbf{P}$ \\
\hline \multirow[t]{2}{*}{ A } & \multirow[t]{2}{*}{30} & \multirow{2}{*}{$\begin{array}{l}9.075+0.2 \\
09\end{array}$} & $\mathrm{AM}=10.325 \pm 0.224$ & 1.249 & 13.62 & 0.706 & 9.669 & $\leq 0.001$ \\
\hline & & & $\mathrm{AF}=10.325 \pm 0.224$ & 0.706 & 13.62 & 1.249 & 9.669 & $\leq 0.001$ \\
\hline \multirow[t]{2}{*}{ B } & \multirow[t]{2}{*}{30} & \multirow{2}{*}{$\begin{array}{l}8.925+0.2 \\
20\end{array}$} & $\mathrm{AM}=9.975 \pm 0.179$ & 1.021 & 11.72 & 0.546 & 6.859 & $\leq 0.001$ \\
\hline & & & $\mathrm{AF}=9.975 \pm 0.179$ & 1.021 & 11.72 & 0.546 & 6.859 & $\leq 0.001$ \\
\hline
\end{tabular}

When the data of the two groups were compared they were found to be statistically insignificant, both after predication $(\mathrm{p}=0.314)$, But the percentage of improvement after medication was $13.62 \%$ in Group A and 11.72 in Group B.

In Group A : RBC (3.21\%), PCV (4.19\%) MCV (1.29), serum iron (12.27\%), percent transferrin saturation $(21.59 \%)$ and total iron binding capacity $(7.16 \%)$, whereas insignificant changes were found in $\mathrm{MCH}(2.21 \%)$ and $\mathrm{MCHC}(0.74 \%)$

In Group B : RBC (4.19\%), PCV (10.37\%), MCV (6.41\%), MCH (7.07\%), serum iron (21.35\%), percent transferrin saturation (34.24\%), and total iron binding capacity $(8.37 \%)$ whereas insignificant change was found in $\mathrm{MCHC}$

Other routine ANC check-up investigation was within normal limit before and after treatment.

\section{Discussion :}

In pregnant woman due to nourishment of fetus, there is dhatukshaya which leads to vatarrudhi, So bruhaniya dravyas has to be taken by her.

In Garbhini -Due to insufficiency of nutritious ahar, upavasa, raktasrava and dauhruda avamana which lead to many of the disorders by vitiating the doshas. Vyadhis manifested due to these are upavishtaka, nagodara, linagarbha, mudhagarbha, kubja, kalithya, palithya, kilasa, kushta, pandu etc in fetus. 
Garbhini pandu is one which is caused mainly due to the increase demand of nutrition by the garbhini which is not being supplemented by adequate nutritional diet.

As the disease is characterised by pandutwa in the body which is caused by alparaktata where rakta (blood) is known to be one among the saptadhatu which has got jeevana karma hence raktavardhana chikitsa becomes important in pregnant woman.

Dhatri Lauha \& Navayasa lauha are selected for the study because of easy availability, less expensive and most of the drugs got deepana (appetizer) pachana (digestive), srotoshodhaka (channel cleasner), tridoshaghna (body humour specifier), rasaraktavardhana (one which increases blood), rasayana (rejuvenative) and balya (one which increases strength) panduhara (one which subsides pallor). The probable mode of action of the two components is as follows :

Raktavardhaka (one which increases blood) property is present in lauha bhasma. If possess significant haematinic \& cytoprotective activity. Iron (Lauha bhasma) also present in amalaki, musta, honey and trace amount in ghee. The drugs which increases digestive juices are chavya, pippalimoola, maricha, shunthi, musta, kutaja, trikatu, musta, chavya, haritaki are amapachana drugs. Haritaki, lauha and shunthi are very useful in vatanuloman. Marich, pippali, shunthi, chitraka are also srotoshodhana. Vidanga \& vibhitaki are krumihara drugs.

Presence of ascorbic acid (vitamin C) is Amalaki has a significants effect. On iron bioavailability from cereals and pulses in vitro musta also contains copper \& manganese which may increase iron metabolism \& haemoglobin synthesis.

Dhatri Lauha \& Novayasa Lauha were administered with honey \& ghee as the vehicle by which they enchance the medicinal qualities of the preparation and also help them to reach the deeper tissue. It's also be a mixture of glucose \& fructose and iron may complex with these sugars for absorption. It may be mentioned here that Allopothic system also uses iron polymaltose complex and ferrous gluconate for therapy with good result.

\section{Conclusion :}

Both drugs are effective to relieve signs \& symptoms of panduroga (IDA) \& provided significant effect in increased haemoglobin percentage in between the groups the herbo - mineral drugs Dhatri Lauha \& Navayasa lauha has proved to be quiet effective in the treatment of garbhini pandu without involving undesirable side effects.

On results of this research work it may be concluded that Dharti Lauha is therapeutically equally good \& sometimes better than Navayasa Lauha.

\section{BIBLOGRPHY-}

[1]. Agnivesha \& Dridhabala, Charak Samhita - Khand 1 \&Chaukhamba Sanskrit Prakashan.

[2]. Ambika Datta Shastri, Sushrut Samhita - Ayurved Tatwa sandeepika, Chaukhamba Sanskrit prakashan, $3^{\text {rd }}$ edition (1974) commentary

[3]. Anant Damodar Athawale Ayurvediya, Astang Sangraha by Vruddha vagbhatta edited muudranalaya 1980.

[4]. Pandit Paraswankum Shastri, Sharangdhar Samhita - edited Chaukhamba orientatia $3^{\text {rd }}$ edition.

[5]. Veni Madhava shstr Joshi, Aayurvedeeya shabda kosha, published by maharashtra Rajya Saahitya samskruti Mandal, Mumbai 1 st\& $2^{\text {nd }}$ khand, 1968.9

[6]. Nadkarni A.K., Indian meteria media, popular Book Depot, Bombay 1954.

[7]. Bhrahmashankar Shastri, Bhavprakash, Part 1st\& 2nd, Chaukhambha sanskrita series, Banaras, 2ndedi. 1949

[8]. V.S. Venkatasubramhanyam, Bhel samhita - 'Bhela' edi.

[9]. Hemraja Sharma and Y.T. Acharya, Kashyap - Samhita - by Kasyapa edited Publication Nirnaga sagar press, Bombay.

[10]. Vaishya Shaligramji, Bangsen Samhita, Bangasen, $1^{\text {st }}$ Ed., Shri venkateshwara Steem Press, Bombay, 1946.Jharkhande Ojha,

[11]. Madanpal Pandit Shaktidhar Shukla, Madanpal nighantu published Navalkishor press, Lucknow $1^{\text {st }}$ edition. 1930.

[12]. Sharma P.V. Kraiyadev nighantu, Pub. Chaukhamba Orientatia varanasi $1^{\text {st }}$ edition 1979.

[13]. Apte V.G, Raj Nighantu Samhita, Dhanvantari Nigantu, Ed. Anandashram Mudranalaya, Pune, 1925.

[14]. Vaisha Shaligramji, Shaligram nighantu - by shaligram vaishya publisher shri venkateshwar steem press Bombay $1^{\text {st }}$ edition 1981.

[15]. Nadkarni K.M., Indian Materia medica - Vol I \& II, Popular Book Depot, Bombay

[16]. Premvati Tiwari, Prasutitantra Part I \& II, Chaukhamba Sanskrit Series.

[17]. Nirmala Joshi, Ayurvedic concepts in Gynaecology, Varanasi, 1965

[18]. Arundatta and Hemadri, 'Sarvangasundari and Ayurvedic Rasayana' Comm. On

[19]. Ashtanga Hidaya, Chokhamba Orientalia, Varanasi, 1982.

[20]. Lifestyle Induced Diseases in Women . Dr.H.S. Palep, Ayurmedline 2002.

\section{Modern text-}

[1]. Park,k park's Textbook of preventive and social medicine 15th Edision,Banarasidas Bhanot publishers,Jabalpur.p392,1997

[2]. Hilliman RS "Hematopoietic Agents: Growth factors minerals and vitamins"Goodman and Gilman's.The pharmacological Basis of Therapeutics.Hardman,J.G.and Limbird,L.E.(eds) McGraw.Hill,New York,10th ed,2003,pp-1487-1517.

[3]. Chatterjea MN,Shinde R Textbook of Medical Biochemistry,Jaypee Brothers,New Delhi,5th ed 2002,pp 187-9.

[4]. Sharma DC,Mathur R Singh PP,Iron metabolism.A Reviev Ind J.Clin Biochem 1993,8,80-101.

[5]. Kasper DL,fauci AS, Longo DL,Braunwald E,Sauser SL, Jameson JL.Harrison's Principal of Internal Medicine,16th ed,vol1.New Delhi,Mc Graw Hill Medical publishing Division 2005.p.588. 
[6]. Shastri A.editor Bhaisajya Ratnavali with Vidyotini hindi explanation panduroga chikitsa,12/3843.16t ed.Varanasi.Chaukhambha Sanskrit Sansthan,2002.p.270-71.

[7]. Lewis SM, Bain BJ,Bates J.Dacie and Lewis practical Haematology.10th ed.New Delhi, Elsevier 2007.p14

[8]. Benoist BD,Mclean E,Egli I ,cogswell M.worldwide prevalence of anemia Geneva, World Health Organization 1993-2005 p7.

[9]. Pandit S,Biswas TK,Debnath pk,Saha AV,Chowdhury U.Shaw BP, etal Chemical and pharmacological evaluation of different ayurvedic preparations of iron evaluation of different ayurvedic preparations of iron J Ethnopharmacol 1999;65:149-56

[10]. Dinesh C.Sharma,Deepa Chandiramani,Manminder Riyat and praveen sharma at scientific evaluation of some ayurvedic preparations for correction of iron deficiency and anemia,indian journal of clinical biochemistry,2007/22(2)123-128.

[11]. Dacie JV,Lewis SM.Practical Haematology.Charchill Livingstone,Edinburg,9th ed.2001,pp-19-49. 